CORRECTION

\title{
Correction: LncRNA-MEG3 inhibits activation of hepatic stellate cells through SMO protein and miR-212
}

Fujun Yu, Wujun Geng, Peihong Dong, Zhiming Huang and Jianjian Zheng

(c) The Author(s) 2022

Cell Death and Disease (2022)13:133; https://doi.org/10.1038/s41419-022-04558-6

Correction to: Cell Death and Disease https://doi.org/10.1038/

s41419-018-1068-x, published online 03 October 2018

The original version of this article unfortunately contained a mistake in Fig. 1A and Fig. 3D.

In the original Fig. $1 \mathrm{~A}$, an incorrect image for the a-SMA immu nocytochemical staining panel was inadvertently included. As shown in a-SMA staining in Fig. $1 \mathrm{~A}$, the image of 4 -week $\mathrm{CCl} 4$ mice (mice were treated $\mathrm{CCl} 4$ for 4 weeks) was uploaded as the $\mathrm{CCl} 4$ mice $(\mathrm{CCl} 4$ mice should be treated $\mathrm{CCl} 4$ for 8 weeks). In the original Fig. 3D, the cell migration image of Ad-Ctrl group was wrongly uploaded as AdMEG3 group. The corrected images are provided below. The authors confirm that these errors do not affect the results and conclusions of the study. The authors apologize for any inconvenience caused. 
A
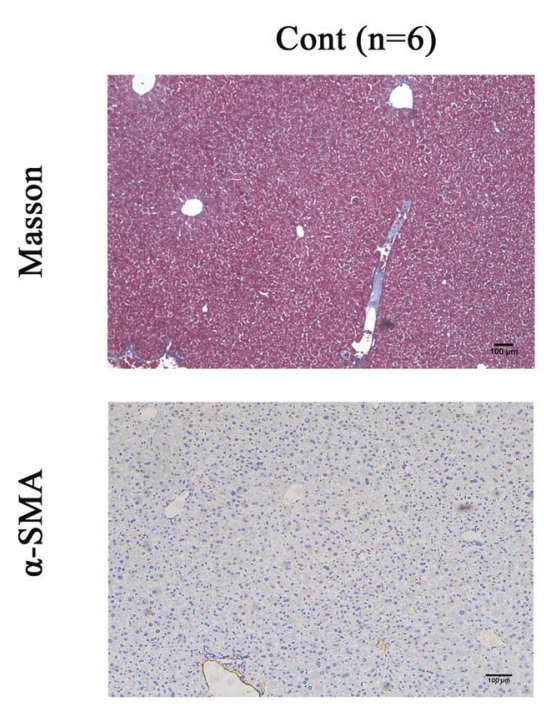

B

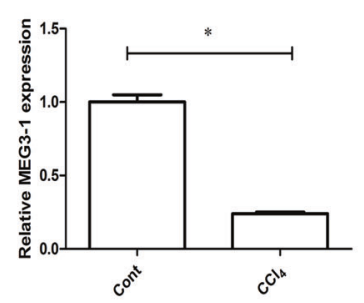

$\mathrm{CCl}_{4}(\mathrm{n}=6)$
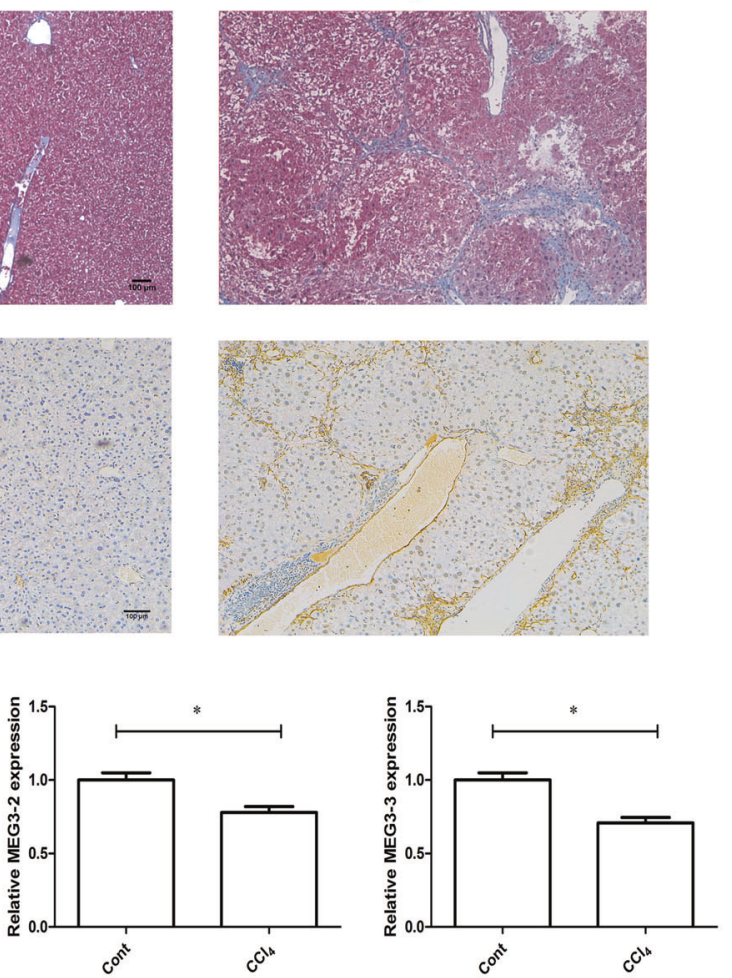

C

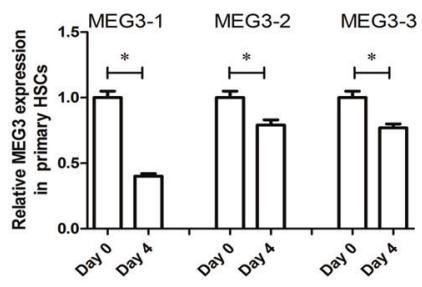

D

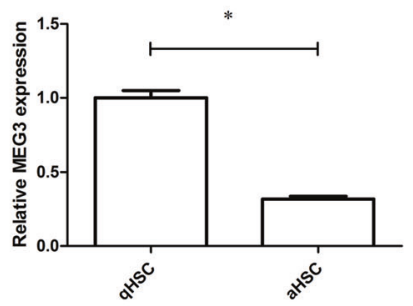

$\mathrm{E}$

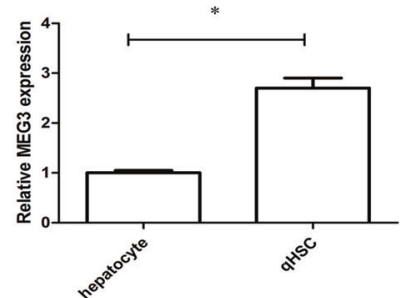

Fig. 1 
A

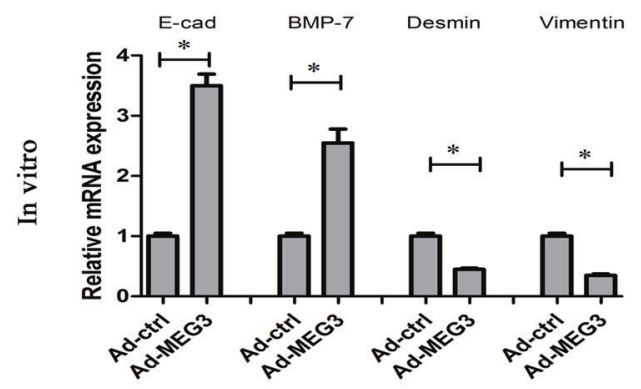

B

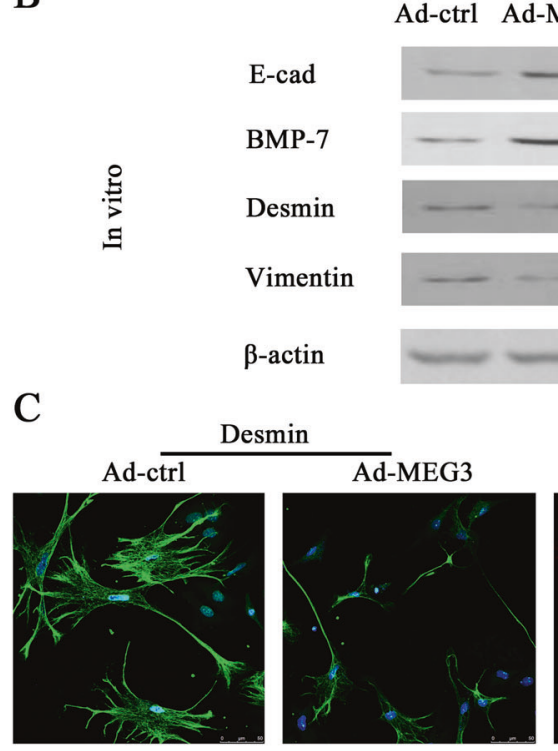

D

Ad-ctrl

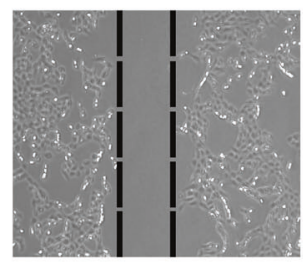

$97 \mathrm{kDa}$

$49 \mathrm{kDa}$

$53 \mathrm{kDa}$

$54 \mathrm{kDa}$

$42 \mathrm{kDa}$
Ad-MEG3

$$
\frac{2}{2}
$$
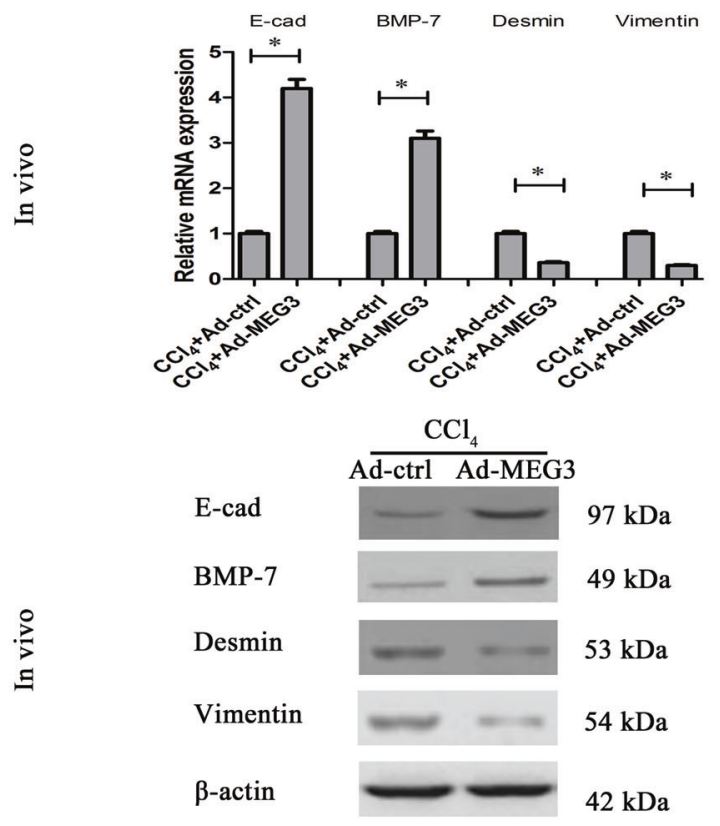

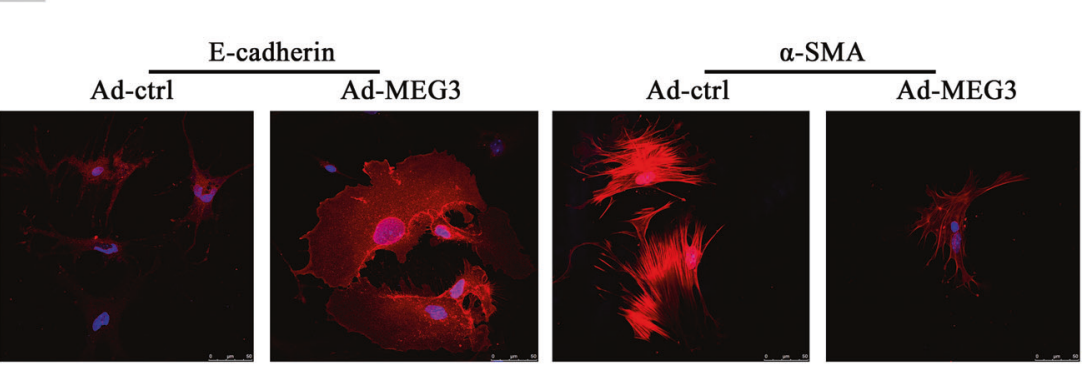

$\mathrm{E}$

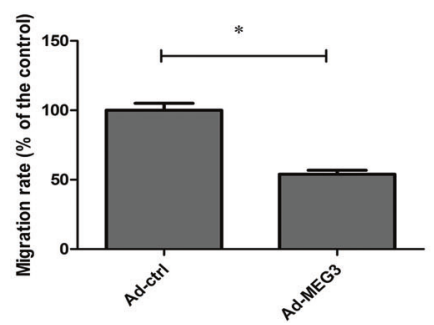

Fig. 3

(c) (7) Open Access This article is licensed under a Creative Commons Attribution 4.0 International License, which permits use, sharing, adaptation, distribution and reproduction in any medium or format, as long as you give appropriate credit to the original author(s) and the source, provide a link to the Creative Commons license, and indicate if changes were made. The images or other third party material in this article are included in the article's Creative Commons license, unless indicated otherwise in a credit line to the material. If material is not included in the article's Creative Commons license and your intended use is not permitted by statutory regulation or exceeds the permitted use, you will need to obtain permission directly from the copyright holder. To view a copy of this license, visit http://creativecommons. org/licenses/by/4.0/.

(c) The Author(s) 2022 